\section{Indian meeting backed despite boycott threats over nuclear tests}

[NEW DELHI] Organizers of the 10th International Congress on Immunology, due to be held in New Delhi in November, are shrugging off demands for a boycott from some members of the American Association of Immunologists (AAI) in protest at India's recent nuclear tests.

But several of those attending the meeting are still seeking to use the opportunity to register their disapproval of the tests and the international proliferation of nuclear weapons.

Eight foreign researchers have withdrawn their registration, but the organizers say they are relieved that a resolution was passed by the association last month expressing its support for the congress.

But they have been upset by a message circulated on the Internet by immediate past AAI president Charles Janeway of Yale University, urging the association not to support the travel of US scientists to India.

Janeway says he never intended to encourage a boycott of the conference, but adds that there is "a serious attempt, spearheaded by Indian scientists working in [the United States], and by myself, to attend the meeting and hold a special session on the Indian nuclear tests. We hope [to] maintain our scientific ties [with India] while protesting at the testing of nuclear weapons by India and Pakistan."

Abul Abbas, professor of pathology at Harvard Medical School, shares similar sentiments, but focuses on the dangers of worldwide nuclear proliferation. "It would be wonderful if scientists from India, Pakistan and all other nations could join to make a statement [at the congress] deploring the current situation," he says.

Some 1,430 overseas scientists have registered for the week-long congress, organized every three years under the aegis of the International Union of Immunological Societies.

The congress's president, Gursaran Prasad Talwar, an emeritus researcher at the International Centre for Genetic Enginnering and Biotechnology in New Delhi, says he is pleased that many of the world's top immunologists plan to attend.

Although basic immunology will be the main focus, the New Delhi conference will for the first time devote three symposia and several workshops to what Talwar says is "beneficial immunology", including vaccines against cancer, allergies and autoimmune diseases such as arthritis. For the first time, the immunology of drug abuse and ocular disease will be discussed. Talwar says 108 interactive' workshops have been designed to benefit young investigators. K.S. Jayaraman

\title{
Congress turns NIH budget into a political football
}

[WASHINGTON] An important Congressional subcommittee has proposed a 9.1 per cent budget increase for the National Institutes of Health (NIH). But it has done so at the expense of several high-profile social programmes, a move that has sharply divided Republicans and Democrats on the panel.

The virtually party-line vote two weeks ago by the Labor, Health and Human Services and Education subcommittee of the House Appropriations Committee suggests dramatic cuts to some social and education programmes. For instance, it would eliminate a $\$ 1.1$ billion programme of home heating assistance for the poor, and an \$871 million summer job training programme for youths.

The subcommittee also suggested halving the Goals 2000 education programme, a favourite of the Clinton administration. But it also seeks to boost the NIH budget by $\$ 1.24$ billion, to $\$ 14.86$ billion, and the Centers for Disease Control and Prevention would receive an unusually large 8.9 per cent increase. The bill continues to ban federal funding for human embryo research.

The bill scraped through the subcommittee by eight votes to seven. A corresponding Senate subcommittee must agree on its own bill, and the two versions must be reconciled and win approval from both legislative houses before becoming law before the new fiscal year begins on 1 October.

It is expected that some proposals will be rejected by the more politically moderate Senate subcommittee, which includes champions of the home heating programme and other affected social programmes.

Although Republicans have boosted NIH research - a politically popular position with both parties - Democrats nevertheless complain that it would take place on the backs of the poor.

President Clinton in a statement called the cuts "arbitrary" and "extreme". "The bill is out of step with our values and the wrong vision for America's future," he said. His comments were echoed by David Obey (Democrat, Wisconsin), the senior Democrat on both the subcommittee and the full Appropriations Committee.

Obey charged that Republicans on the panel "have decided to take the $[\mathrm{NIH}]$ funding out of the hides of the weakest and most vulnerable people in society". But he did not try to amend the bill to restore the social and education programme cuts and decrease the NIH boost.

Subcommittee Republicans, led by the chairman, John Porter (Republican, Illinois), insisted that cuts were being proposed not to finance medical research but because the

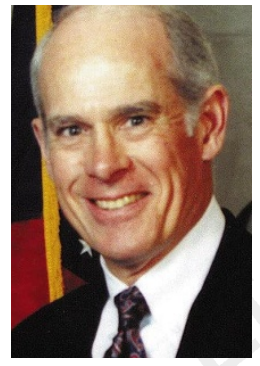

Porter: argues social policies deserve cuts. heating assistance programme begun during an energy crisis in 1980 is an anachronism now that energy prices have dropped, and that the summer job training programme has not made young people more employable.

But advocates for biomedical research praise the subcommittee's actions. "We are obviously pleased about the numbers for NIH," says David Moore, a lobbyist for the Association of American Medical Colleges.

Timothy Leshan, the director of public policy at the American Society for Cell Biology and a lobbyist for biomedical research funding, says that few scientists support cutting social programmes. But he adds: "there is political reality, and that's why they had to make the choices they did." The subcommittee must fund labour, education, social and health programmes from the same bill.

The money available for non-mandatory social and education programmes and medical research has remained virtually the same as last year because of a 1997 agreement that imposed caps on such 'discretionary' federal spending. Thus, to find an extra $\$ 1.24$ billion for NIH, and a $\$ 208$ million boost for the Centers for Disease Control and Prevention, the committee had to slash other programmes.

If the subcommittee's proposals prevail in their current form, the final version would risk a presidential veto in a Congressional election year. Rather than risk this, it seems likely that either the social spending will be restored to some degree in the Senate - and prevail in negotiations between the two bodies - or that the Republican leaders of Congress will increase the total money in the bill.

The latter could be achieved by tapping the growing budget surplus, or by breaching the spending caps in the 1997 agreement, which is allowed in narrow circumstances. "A lot of people believe there's going to have to be some more money put into that bill to resolve this issue," says Moore.

The full House Appropriations Committee is scheduled to meet next week to decide whether to endorse its subcommittee's recommendations.

Meredith Wadman 